\title{
The Process of Land Consolidation as the Element of Arranging Rural Space on the Example of the Łubka and Zaliszcze Villages
}

\author{
Alicja Baranowska ${ }^{1 *}$, Krystyna Zarzecka² $^{2}$ Zbigniew Rudzki ${ }^{3}$ \\ 1 Department of Agriculture, Pope John II State School of Higher Education in Biała Podlaska, ul. Sidorska \\ 95/98, 21-500 Biała Podlaska, Poland \\ 2 Department of Agrotechnology, University of Natural Sciences and Humanities in Siedlce, ul Prusa 14 B, 08- \\ 110 Siedlce, Poland \\ 3 Voivodeship Office of Surveying in Lublin, Branch Office in Biała Podlaska, ul. 41 Brzeska Street, 21-500 Biała \\ Podlaska, Poland \\ * Corresponding author's e-mail: alabar@tlen.pl
}

\begin{abstract}
The aim of this work is to present the selected effects of consolidation processes conducted in 2011-2014 within the Łubka region, Siemien commune and within the Zaliszcze area, Podedwórze commune, Parczew district, Lublin Voivodeship. The consolidation activities within Łubka region were conducted over the area of 156.2937 ha and involved 60 participants. Within the Zaliszcze region, the general development area amounted to 1174.2580 ha and involved 152 participants. The project of land consolidation was developed by the Voivodeship Office of Surveying in Lublin, Branch Office in Biała Podlaska. In order to assess the basic results of land consolidation, the technical-spatial parameters were applied (the index of reducing the number of plots and extension of their surface). The main effects of the conducted process of consolidation include: decrease of a general number of record plots and an increase of the average surface of them within the region, which resulted in a reduction of the number of plots and decrease of the average surface of the plot in the farmstead. Furthermore, in conjunction with the change in the distribution of individual record plots, the farm layout has improved. Numerous agri-technical and recultivating works were also conducted and a functional network of municipal roads was created.
\end{abstract}

Keywords: rural areas, land consolidation, consolidation effects

\section{INTRODUCTION}

In Poland, rural areas are characterized by exceptional natural values. They perform a vastly important economical, economic, social and cultural role. According to the Head Office of Geodesy and Cartography, these areas constitute $29.1 \mathrm{M}$ ha, which amounts to $93.0 \%$ of the surface of the country; they are inhabited by $39 \%$ of the population, $55.5 \%$ of the surface of the rural area is the surface of farmsteads. However, in the structure of the surface of farmsteads, $89.6 \%$ are usable agricultural lands, $5.8 \%$ forests and forest lands and $4.6 \%$ the remaining lands [Central Statistical Office, 2017].

However, in Poland, the countryside is characterized by an unfavourable area struc- ture, large fragmentation of farmsteads (most of which do not exceed 5 ha). In the structure of farmsteads, $70 \%$ are usable agricultural lands smaller than 5 ha, over $25 \%$ are the farms of 5-20 ha, and only $5.5 \%$ are farms over 20 ha [Central Statistical Office, 2011].

Also in Lublin Voivodeship, within the general number of farmsteads, $80.2 \%$ are small farms with small surface - from 1 to 10 ha. On the other hand, the farms over 10 ha constitute only $18.8 \%$ [Statistical Office in Lublin, 2017].

The reasons behind the agrarian fragmentation of Polish countryside were, inter alia: partition periods, years after regaining independence (so-called land hunger), the agrarian reforms (introduced by the Acts of 1920 and 1925 and by the Decree of 1944), and also the overpopulation of 
Polish countryside, or freedom of division agricultural parcels [Bański, 2010].

Over the years, the change of agrarian structure developed through the subdivision or integration of the lands. In 1923, the first, innovative Act on the land consolidation was introduced [Journal of Laws No. 92, item 718], on the basis of which, until the end of 1938, over 5 million ha of farm and forest lands were consolidated. During the subsequent years, the consolidation proceedings were conducted with different intensity, which resulted from the political and political-economic situation in the country. The advancement was made by the Act of 1982 on the consolidation and exchange of the lands [Journal of Laws No. 11, item 80]. However, already at the beginning of the nineties of the $20^{\text {th }}$ century, a smaller number of performed consolidation works was noticed. This process also continued in the following years [Siuta and Żukowski, 2018].

Currently, one of the most important needs of Polish agriculture is the performance of consolidation works. This classical formallegal and technical solution enables a holistic improvement related to the conditions of management in agriculture and forestry. The aim of the consolidation works was to create more favourable conditions of managing through the improvement of area structure of the farmsteads, forests and forestlands, introduce rational topography of lands layouts, and adapt the estate borders to the system of land reclamation devices, roads and relief [Journal of Laws of 28 May 2014, item 700]. According to Taszkowski et al. [2016] as the result of performing land consolidation, the achieved effects are not only connected with the improvement of the functioning of the farmsteads, but also with the improvement of the quality of cadastral data.

The process of land consolidation fits well into the main objective of the Rural Development Program for 2014-2020, the main assumption of which is to: improve the competitiveness of agriculture, implement balanced managing of the natural resources, carry out the actions in the field of climate and balanced territorial development of rural areas [Rural Development Programme, 2014].

An important role in rural space arrangement is played as well by the works regarding the development of post-consolidation terrain which include, inter alia: the construction and reconstruction of the roads, correction of technical parameters of the land detailed improvement devices, the liquidation of unnecessary balks and recultivation treatments [Journal of Laws of 28 May 2014, item 700].

The process of consolidation and exchange of the lands, however, is very complex, labour-intensive, expensive and difficult to implement, and primarily it requires the acceptance of the local community. Currently, the needs of conducting the consolidation works are immensely large, and the biggest need for them concerns the south-eastern Poland. Unfortunately, the current consolidation works are being conducted only on approximately several thousand hectares per year [Janus, 2011].

The aim of this paper is to present the selected effects of consolidation proceeding conducted in the Łubka village region, Siemien and Zaliszcze commune, Podedwórze commune, located in Parczew district, in the Lublin Voivodeship.

\section{MATERIAL AND METHODS}

The territorial scope of the research encompassed the registration area Lubka $\left(51^{\circ} 38^{\prime} 24^{\prime \prime} \mathrm{N}\right.$ $\left.22^{\circ} 42^{\prime} 51^{\prime \prime} \mathrm{E}\right)$ and Zaliszcze ( $51^{\circ} 38^{\prime} 53^{\prime \prime} \mathrm{N}, 23^{\circ}$ $9^{\prime} 18^{\prime \prime} \mathrm{E}$ ). The process of land consolidation was conducted by the Voivodeship Office of Surveying in Lublin, Branch Office in Biała Podlaska in 2011-2014. The land consolidation projects were realized by means of Rural Development Program for 2007-2013: the action "Improving and developing infrastructure connected with the development and adaptation of agriculture and forestry".

The Łubka village is located in the Siemien commune, in the eastern part of Parczew district, in the Lublin Voivodeship. It is located: 6 kilometres from the headquarters of Siemien commune, 18 kilometres from the headquarters of the district - Parczew and 55 kilometres from the capital of the Voivodeship - Lublin. The basis of the communication system is formed by two voivodeship roads with the total length of 16.616 $\mathrm{km}$ and district and commune road system. On the area covered by the consolidation, there are mostly arable lands, classified as soil valuation classes: IVa, IVb and $\mathrm{V}$, and on the grasslands, mostly the soils of soil valuation class IV and V. The consolidation proceeding of the Lubka village lands was initiated by the Order of Parczew Starost No. GN.III.6622.2.1.2011 of 23.02.2011 at the request of $69 \%$ consolidation participants, 
who owned $70 \%$ of the surface of the land. The consolidation project encompassed the surface of 156.2937 ha.

The Zaliszcze village is located in the northern part of Podedwórze commune, Parczew District, Lublin Voivodeship. It is located $7 \mathrm{~km}$ from the headquarters of Podedwórze commune, $23 \mathrm{~km}$ from the headquarters of the district - Parczew and $72 \mathrm{~km}$ from the Voivodeship capital - Lublin. The basis of the communication system of the commune is formed by a voivodeship road with the length of $9.4 \mathrm{~km}$ and the network of district and municipal roads. Arable lands, classified as soil valuation classes: IVa, IVb, and V are prevailing. The consolidation process was initiated by the Parczew Starost Order No. GN.III.6622.6.1.2011 of 01.12.2011 at the request of 152 participants, who owned $90 \%$ of the land surface. The consolidation process encompassed the surface of 1174.1888 ha.

The main aims of consolidation works are: liquidation of the so-called geographical patchiness, designing regular-shaped plots, adapted to land improvement system, relief and other terrain situation elements, correction of the course of record plot borders (construction areas), increasing their average surface and decreasing the number of them per one farmstead, designing and reconstruction of agricultural access roads to fields and habitats, modernization of detailed land improvement devices, and development of cadastral documentation on the basis of applicable standards.

The scope of the activities encompassed the development of the project of consolidation (preparation of geo-legal documentation), as well as execution of the post-consolidation land use and planning project, comprising, inter alia, construction and reconstruction of commune roads, correction of the course and improvement of technical parameters of ditches, and the realization of other treatments resulting from the consolidation project. The complex modernization of land record was executed as well.

In the assessment of the effects of the land consolidation process, the following technicalspatial parameters were taken into account: the average number of record plots and the average surface of the record plot within the region before and after consolidation, as well as the average number of record plots and the average surface of record plot in a farmstead before and after consolidation (land layout) [Woch, 2006].

\section{RESULTS AND DISCUSSION}

As a result of conducted research, it was found that the Łubka and Zaliszcze record areas were characterized by high proportion of usable agricultural lands in the general surface of the farmlands (Table 1). Within Łubka, farmlands (R) constituted $62.21 \%$, whereas within Zaliszcze $-43.40 \%$ of the total farmlands. However, permanent meadows ( $\mathrm{E}$ ) and permanent pastures (Ps) constituted: $10.30 \%$ and $9.14 \%$ (Lubka area) and $24.00 \%$ and $16.02 \%$ (Zaliszcze area) of the farmland structure, respectively (Table 1).

As the result of conducted research, it was found that the record areas Łubka and Zaliszcze had unfavourable area structure of individual farmsteads (Table 2). Small farms, with the sur-

Table 1. The share of farmlands in general surface of record areas Łubka and Zaliszcze

\begin{tabular}{|c|c|c|c|c|}
\hline \multirow{2}{*}{ Farmlands } & \multicolumn{2}{|c|}{ Łubka area } & \multicolumn{2}{|c|}{ Zaliszcze area } \\
\hline & [ha] & {$[\%]$} & [ha] & {$[\%]$} \\
\hline Farmlands - R & 97.1448 & 62.21 & 509.573 & 43.40 \\
\hline Permanent meadows $-€$ & 16.0800 & 10.30 & 281.85 & 24.00 \\
\hline Permanent pastures - Ps & 14.2700 & 9.14 & 188.0629 & 16.02 \\
\hline Forests - Ls & 15.2178 & 9.74 & 103.8729 & 8.85 \\
\hline Lands under ditches - w & 1.8300 & 1.17 & 21.81 & 1.86 \\
\hline Wastelands $-\mathrm{N}$ & 2.5800 & 1.65 & 20.68 & 1.76 \\
\hline Roads - dr & 3.2400 & 2.07 & 27.02 & 2.30 \\
\hline Lands under the flowing Surface waters $-W p$ & 0.5600 & 0.36 & 17.28 & 1.47 \\
\hline *Other & 5.2400 & 3.36 & 4.04 & 0.34 \\
\hline Total & 156.1626 & 100 & 1174.1888 & 100 \\
\hline
\end{tabular}

\footnotetext{
* Other - lands under the stagnant surface waters [Ws], wooded and bushed lands [Lz].
} 
face of usable agricultural land from 1 to 5 ha were prevailing. In the total number of farmsteads, they constituted respectively $77.14 \%$ (Lubka area) and $41.44 \%$ (Zaliszcze area). The farms with the surface of usable agricultural land exceeding 20 ha appeared only in Zaliszcze area and constituted only $14.42 \%$ of total farms (Table 2 ).

What is more, a huge fragmentation of record plots was identified. The number of record plots in the Lubka area was 332, and in the Zaliszcze area -458 . The average surface of record plot was small, and it constituted 0.4707 ha and 2.5639 ha in the Łubka and Zaliszcze areas, respectively. However, the average surface of record plot in the farmhouse was only 0.2802 ha (Łubka area) and 1.6998 ha (Zaliszcze area) (Table 3).

Such significant fragmentation of agrarian structure has a negative influence on the production-economic results of farmsteads. It also precludes from implementing new agricultural equipment. Moreover, it impedes the ability of Polish agriculture to compete with other the ag- riculture of European Union countries. In Poland, only $30 \%$ of usable agricultural lands are in spatially larger farms (over $50 \mathrm{ha}$ ), whereas this contribution in most EU countries is 80-90\% [Woś, 2014; Stańko and Mikuła, 2016].

The rural areas in Poland require deep structural changes, concerning, inter alia, the size of the farmsteads and their spatial structures [Woch, 2006]. According to Siuta and Żukowski [2010], the defective spatial structures of agrarian use of land in Poland are the basic barrier in the modernization of agriculture and in the protection of the soil surface from progressive degradation. The process of consolidation and exchange of the lands is a chance for a multifunctional and balanced development of rural areas [Bielska, 2012]. In order to diminish the surface with defective layout realistically, the consolidation should be performed on at least 50.000 ha per year [Jędrzejek et al., 2014].

The economic effects of realizing the land consolidation and exchange process achievedin

Table 2. The area and quantity structure of individual farmsteads - Łubka and Zaliszcze record area

\begin{tabular}{|c|c|c|c|c|}
\hline $\begin{array}{c}\text { Surface of usable } \\
\text { agricultural land [ha] }\end{array}$ & $\begin{array}{c}\text { Number of } \\
\text { farms }\end{array}$ & $\begin{array}{c}\text { Contribution } \\
\text { in the total } \\
\text { number of farms [\%] }\end{array}$ & $\begin{array}{c}\text { Total Surface } \\
\text { of farms [ha] }\end{array}$ & $\begin{array}{c}\text { Contribution in the total } \\
\text { surface of farms [\%] }\end{array}$ \\
\hline \multicolumn{7}{|c|}{ Łubka record area } \\
\hline $1.00-5.00$ & 27 & 77.14 & 71.8430 & 48.55 \\
\hline $5.01-10.00$ & 6 & 17.15 & 45.3923 & 30.68 \\
\hline $10.01-20.00$ & 2 & 5.71 & 30.7400 & -100 \\
\hline over 20.01 & - & - & -147.9753 & 9.65 \\
\hline Total & 35 & 100 & 112.3623 & 16.76 \\
\hline \multicolumn{7}{|c|}{ Zaliszcze record area } \\
\hline $1.00-5.00$ & 46 & 41.44 & 195.1191 & 31.20 \\
\hline $5.01-10.00$ & 26 & 23.42 & 363.2477 & \\
\hline $10.01-20.00$ & 23 & 20.72 & 493.6089 & 100 \\
\hline over 20.01 & 16 & 14.42 & 1164.3380 & \\
\hline Total & 111 & 100 & \\
\hline
\end{tabular}

Table 3. The results of land consolidation and exchange process within the Łubka and Zaliszcze areas

\begin{tabular}{|l|c|c|c|c|c|c|c|}
\hline \multicolumn{1}{|c|}{ Specification } & \multicolumn{1}{|c|}{$\begin{array}{c}\text { Condition } \\
\text { before } \\
\text { the } \\
\text { consolidation }\end{array}$} & Condition after & \multicolumn{1}{|c|}{$\begin{array}{c}\text { The result } \\
\text { of the } \\
\text { consolidation } \\
\text { consolidation } \\
\text { process [\%] }\end{array}$} & $\begin{array}{c}\text { Condition } \\
\text { before } \\
\text { the } \\
\text { consolidation }\end{array}$ & $\begin{array}{c}\text { Condition after } \\
\text { the } \\
\text { consolidation }\end{array}$ & $\begin{array}{c}\text { The result } \\
\text { of the } \\
\text { consolidation } \\
\text { process [\%] }\end{array}$ \\
\cline { 2 - 8 } & \multicolumn{2}{|c|}{ Łubka area } \\
\hline $\begin{array}{l}\text { The number of record plots } \\
\text { within the area }\end{array}$ & 332 & 178 & 46.39 & 458 & 373 & 18.56 \\
\hline $\begin{array}{l}\text { Average record plot surface } \\
\text { within the area [ha] }\end{array}$ & 0.4707 & 0.8781 & 86.55 & 2.5639 & 3.1481 & 18.56 \\
\hline $\begin{array}{l}\text { Average number of record plots } \\
\text { in farmstead }\end{array}$ & 6.15 & 3.07 & 50.00 & 3.5 & 2.8 & 20.00 \\
\hline $\begin{array}{l}\text { Average record plot surface } \\
\text { in farmstead [ha] }\end{array}$ & 0.2802 & 0.4291 & 53.14 & 1.6998 & 1.9642 & 15.55 \\
\hline
\end{tabular}


the area of Łubka and Zaliszcze were presented in Table 3. It was found that as a result of consolidation process, the the number of record plots decreased by $46.39 \%$ (Lubka area) and $18.56 \%$ (Zaliszcze area) and the increase of the average surface of the plot within the area and in farmstead amounted to $86.55 \%$ and $50.00 \%$ (Lubka area) and of $18.56 \%$ and $20.00 \%$ (Zaliszcze area), respectively. The average farm plot surface was expanded by $53.14 \%$ (Łubka) and $15.55 \%$ (Zaliszcze) respectively (Table 3 ). The above-mentioned results allow concluding that more visible economic effects of the realization of land consolidation and exchange process were obtained in the Łubka area than in the Zaliszcze area. It resulted mostly from the worse farmstead layout before the consolidation in the Łubka area than in the Zaliszcze area. Similar results were obtained by Woch [2006], indicating the dependence between the condition of the land layout and the effects of consolidation. According to the author, the worse was the layout before the consolidation, the better the results after land consolidation.

What is more, the effects of the realization of land consolidation process in the Łubka and Zaliszcze areas were: the abolition of shared ownership, regulation of the course of estates borders, launch of land record accordingly to the applicable standards, actualizations of current and launching of new land registers for record plots created as a result of consolidation. These activities defined the current legal condition of estates and ensured the safety of the real estate. According to Taszkowski et al. [2016], the basic geo-legal procedures which have a direct influence on the improvement of the quality of cadastral data are primarily land consolidations. However, the quality of the cadastral data is the basis for the estate cadastre functioning, which is the basis of the Estate Information Integrated System.
The above-mentioned results of the consolidation process gave rise to the series of investment activities, defined as post-consolidation land use and planning, which were connected with arrangement and organization of agricultural area. The priority activities comprised the reconstruction and modernization of the roads, improvement of parameters and construction of technical land improvement devices (Table 4). This enabled to reduce the costs of conducting agricultural business by shortening the time of arrival to particular plots and lead to the reduction of expenses on agricultural equipment and devices depreciation. According to Trystuła [2008], the land consolidation process enables to increase the effectiveness of managing, mechanization of exercised agricultural works, and thus leads to a satisfactory condition of technical infrastructure.

According to Balawejder et al. [2015], the land consolidation process plays a significant role in arranging rural areas, it influences the citizen's life comfort, stimulates the development of functions exercised by these areas, inter alia, in the economic, social and environmental sphere. Through the changes in ownership and use structure, it provides the possibility to separate the functional-spatial areas, at the same time removing numerous potential conflicts. Nevertheless, this is an immensely time-consuming and complex process, both for the landowners and for the surveyors. According to Basista [2013], an interesting solution would be creating on the internet a Geoportal, which would provide quick and easy access for the consolidation participants to the current information on their plots and the stages of the consolidation process. However, Pijanowski [2011], by comparing the competences of administration responsible for agricultural-administrative works in Poland and in the Federal Republic of Germany, stated that in Poland - in comparison to the Federal Republic of Germany - there is an excessive disper-

Table 4. Investment activities executed by means of realization of post-consolidation planning and management - the recording area of Łubka and Zaliszcze

\begin{tabular}{|c|c|c|c|}
\hline Specification & $\begin{array}{l}\text { The units of } \\
\text { measurement }\end{array}$ & Łubka record area & Zaliszcze record area \\
\hline \multicolumn{4}{|c|}{ Roads reconstruction: } \\
\hline - asphalt & \multirow{4}{*}{$\mathrm{km}$} & - & 2.37 \\
\hline - made of road aggregate & & 1.19 & 3.32 \\
\hline - on the floor gravel & & 0.93 & 9.84 \\
\hline $\begin{array}{l}\text { Improvement of technical parameters of land } \\
\text { improvement devices }\end{array}$ & & 4.17 & 23.00 \\
\hline $\begin{array}{l}\text { The construction of culverts on the ditches of } \\
\text { detailed land improvement devices }\end{array}$ & Pc. & 6.00 & 56.00 \\
\hline
\end{tabular}




\section{Selected elements of post-consolidation planning and management}
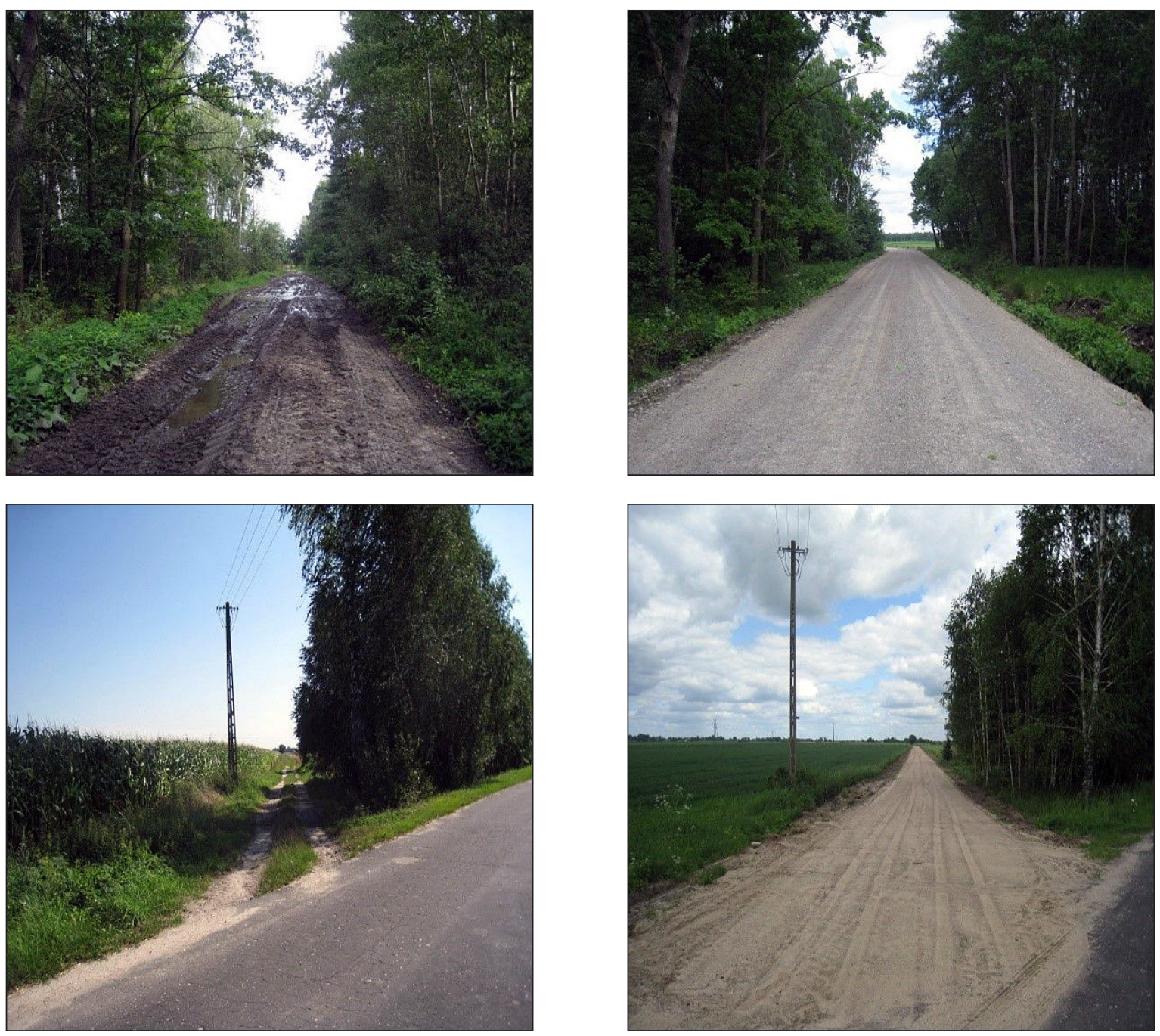

Figures 1-4. The condition of the roads before and after land consolidation - Zaliszcze village
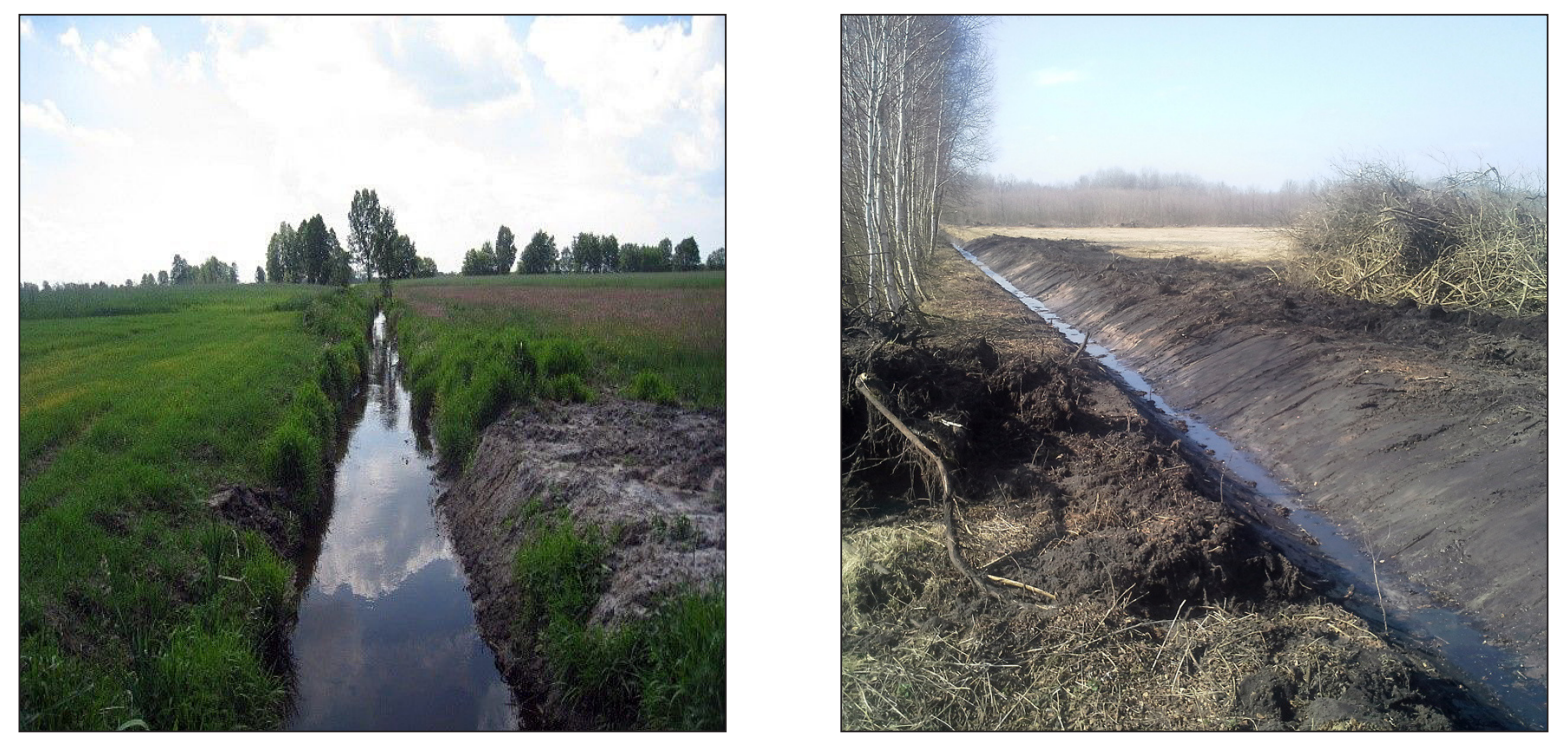

Figures 5-6. Improvement of technical parameters of land improvement devices - Łubka and Zaliszcze villages 
sion of competences between the Marshal, Starost and Voivode and the series of other legal persons, which significantly impedes and complicates the realization of consolidation proceedings.

\section{CONCLUSIONS}

1. The realization of the land consolidation process has contributed to the modernization and reconstruction of the spatial structure of the Łubka and Zaliszcze Villages. The new spatial layout of the plots was created, which enables to conduct the agricultural planning and management rationally.

2. A series of works of investment character was exercised, related to the post-consolidation planning and management of the terrain. The issue of agricultural transport roads was resolved; the technical parameters of the detailed land improvement devices were fixed.

3. It was found that a series of informational and educational activities should be undertaken, which would promote the desirability of the realization of land consolidation process and the benefits resulting from the realization of this process among the local communities in a comprehensible way.

\section{REFERENCES}

1. Balawejder M., Bielska A., Gniadek J., Król Ż., Kupidura A., Leń P., Oleniacz G., Sobolewska-Mikulska K., Turek A. 2015. Land consolidations as a determinant of multi-functional development of rural areas. Anna Bielska, Przemysław Leń (Eds.), University of Information Technology and Management in Rzeszów, Rzeszów.

2. Bański J. 2010. Atlas of Polish Agriculture. The Stanisław Leszczyński Institute of Geography and Spatial Management. Polish Academy of Sciences. Warsaw.

3. Basista I., 2013. Geoportal for the purpose of land consolidation and exchange process. Geomatics Yearbook, XI 5, (62), 7-12.

4. Bielska A. 2012. Impact of the land consolidation process on multi-functional, sustainable development of rural areas. Infrastructure and Ecology of Rural Areas, 1/II, 5-14.

5. Central Statistical Office. 2011. Land use. General Farm Census 2010. Warsaw.

6. Central Statistical Office. Department of Regional Research and Environment. 2017. Rural areas in Poland 2016. Warsaw.
7. Janus J. 2011. Integrated system of formulating land layouts in the countryside. Habilitation thesis. Kraków. Rural Technical Infrastructure Commission Polish Academy of Sciences.

8. Jędrzejek A., Woch F., Szymański L. 2014. Assessment of fragmentation of agricultural farms in defining the size of consolidation works in Poland. Geodesic Review, 10, 3-10.

9. Journal of Laws of 26 March 1982, No 11, item 80. Act on land consolidation and exchange.

10. Journal of Laws of 28 May 2014, item 700. Notice of the Marshall of the Sejm of the Republic of Poland of 12 March 2014 on publication of the consolidated text of the Act on land consolidation and exchange.

11. Journal of Laws of 31 July 1923, No 92, item 718. Act on land consolidation.

12. Pijanowski J., M. 2012. Comparative Study of structure and competence of administration responsible for arrangement-agricultural works in Poland and in the Federal Republic of Germany. Infrastructure and Ecology of Rural Areas PAN, 2/ II, 17-27.

13. Rural Development Programme 2014-2020. 2014. Ministry of Agriculture and Rural Development, Warsaw.

14. Siuta J., Żukowski B. 2010. Development and potential threats to agroecosystems. Part IV. Threats to agroecosystems. Protection of Environment and Natural Resources, 42, 80-103.

15. Siuta J., Żukowski B. 2018. Polish dilemmas of land consolidation and rural areas management. Part 1. Land Consolidation. Ecological Engineering, 19 (3), 1-16.

16. Stańko S., Mikuła A. 2016. Changes in the area astructure of agricultural farms in EU-15 countries and in Poland. Scientific Journals of the Warsaw University of Life Sciences, Problems of World Agriculture, 16 (1), 234-244.

17. Statistical Office in Lublin. 2017. Agriculture in the Lublin Voivodeship in 2016.

18. Taszakowski J., Janus J., Mika M., Leń P. 2016. Cadastral land consolidations in the process of modernizationofrealestatecadastreinPoland. Infrastructure and Ecology of Rural Areas. Polish Science Academy, Kraków, 1/II, 375-394.

19. Trystuła A. 2008. Land consolidation as one of the components of rural space management in Poland and in Lithuania. Water-Environment-Rural Areas, 8,2a (23), 179-190.

20. Woch F. 2006. Assessment of organizationaleconomic effects of land consolidation. Puławski Notebook, 142, 561-574.

21. Woś A. 2004. In search of Polish agriculture development. National Research Institute of Agricultural and Food Economics Warsaw. 